\title{
Influence of Apolipoprotein E Polymorphism on Apolipoprotein B-100 Metabolism in Normolipemic Subjects
}

\author{
Thomas Demant, Dorothy Bedford, Christopher J. Packard, and James Shepherd
}

Institute of Clinical Biochemistry, Glasgow Royal Infirmary, Glasgow G4 OSF, Scotland

\begin{abstract}
This study examined apolipoprotein (apo) B metabolism in normolipemic subjects homozygous for the apo $E_{2}(n=4)$, apo $E_{3}$ $(n=5)$, or apo $\mathrm{E}_{4}(n=5)$ phenotype. Radioiodinated very low density lipoprotein (VLDL $\mathbf{L}_{1}$ ) (ultracentrifuge flotation rate $\left[\mathrm{S}_{\mathbf{f}}\right]$ $60-400)$ and $V L D L_{2}\left(S_{1} 20-60\right)$ were injected into volunteers and the conversion of apo $B$ was followed through intermediate density lipoprotein (IDL) to low density lipoprotein (LDL). Subjects homozygous for $\mathrm{E}_{3}$ converted $\sim 50 \%$ of $\mathrm{VLDL}_{2}$ to LDL, the remainder being lost by direct catabolism. Those with the $E_{2}$ phenotype produced less $V_{L D L}$ but converted more of it to $\mathrm{VLDL}_{2}$ (compared to $\mathrm{E}_{3}$ subjects). They displayed a characteristic dyslipidemia with the presence of slowly catabolized $V_{L D L}$ and $V_{1 D L}$ remnants. LDL levels were low owing to increased direct catabolism of $\mathrm{VLDL}_{2}$ and $I D L$ and a reduced efficiency of delipidation; only $25 \%$ of $\mathrm{VLDL}_{2}$ apo $\mathrm{B}$ was directed to $\mathrm{LDL}$ production. In contrast, $\mathrm{E}_{4}$ subjects converted more $V_{L D L}$ apo $B$ to LDL than $E_{3}$ subjects. About $70 \%$ of $\mathrm{VLDL}_{2}$ apo B was found in LDL; direct catabolism of VLDL and IDL was reduced as was the fractional catabolic rate of LDL (0.2 vs. 0.26 in $E_{3}$ subjects). These changes in the VLDL $\rightarrow$ IDL $\rightarrow$ LDL metabolic cascade can in part be explained by alterations in hepatic LDL receptors with $E_{2}$ subjects having higher and $E_{4}$ subjects lower activities than those in $\mathrm{E}_{3}$ homozygotes. (J. Clin. Invest. 1991. 88:1490-1501.) Key words: catabolism • modeling • kinetics • synthesis • very low density lipoprotein
\end{abstract}

\section{Introduction}

In humans the gene locus for apolipoprotein $\mathrm{E}$ (apo $\mathrm{E}$ ) is polymorphic with three alleles $\left(E_{2}, E_{3}\right.$, and $\left.E_{4}\right)$ being present in all populations studied so far (1-3). The commonest variant is $E_{3}$ for which $\sim 70 \%$ of Caucasians are homozygous. It codes for a protein of 299 amino acid residues, which although minor in terms of plasma concentration, has an important role in regulating lipoprotein metabolism by virtue of its ability to act as a ligand for specialized lipoprotein receptors. Individuals who possess the $E_{2}$ allele synthesize an apo $E$ in which the arginine residue at position 158 is replaced with cysteine as the result of a $\mathrm{C} \rightarrow \mathrm{T}$ point mutation. Those with $\mathrm{E}_{4}$ in contrast generate a

Dr. Demant's current address is Institut fur Klinische Chemie, Klinikum Grosshadern, D-8000 Munich 70, Federal Republic of Germany. Address reprint requests to Dr. Demant.

Received for publication 2 February 1991 and in revised form 27 June 1991.

\section{J. Clin. Invest.}

(c) The American Society for Clinical Investigation, Inc. $0021-9738 / 91 / 11 / 1490 / 12 \$ 2.00$

Volume 88, November 1991, 1490-1501 product with an arginine at residue 112 compared with cysteine in apo $E_{3}$. These mutations in the protein sequence cause charge changes which are readily detected by isoelectric focusing of very low density lipoproteins (VLDL) apoproteins (4) or by isoelectric focusing of plasma followed by detection with immunoblotting $(5,6)$. Structure-function studies of apo E have revealed that a domain covering amino acid $140-160$ is of critical importance in receptor interaction. The $\mathrm{E}_{2}$ mutation occurs in this region and in vitro studies have demonstrated that the resulting protein has impaired receptor-binding properties $(4,7)$.

Epidemiological surveys have demonstrated that the apo $\mathrm{E}$ polymorphism has a significant impact on plasma cholesterol and apolipoprotein B (apo B) levels (3). Compared to apo $E_{3}$ homozygotes, those who are homozygous for the $\mathrm{E}_{2}$ allele exhibit plasma cholesterol levels that are 10-15\% lower while the opposite holds for those who are $\mathrm{E}_{4}$ homozygotes. Examination of the lipoprotein profile in the various apo $\mathrm{E}$ phenotypes has revealed that the gradation in plasma cholesterol from $E_{2}$ to $E_{3}$ to $E_{4}$ homozygotes is due to an increase in the level of low density lipoprotein (LDL). However, $\mathrm{E}_{2}$ homozygotes have higher VLDL cholesterol levels and display a dyslipidemia that is qualitatively similar to that seen in type III hyperlipidemia. The latter is usually associated with $\mathrm{E}_{2}$ homozygosity and inheritance of another as yet unidentified mutation that causes an elevation of plasma lipid levels (8). A number of studies have examined the metabolic changes underlying the altered lipoprotein profiles associated with the apo E polymorphism. Chylomicron clearance is reduced in subjects possessing the $E_{2}$ allele, whereas $\mathrm{E}_{4}$ heterozygotes and homozygotes show accelerated clearance $(9,10)$. Metabolic studies of $L D L$ apo $B$ have shown that type III and, to a lesser extent, $E_{2}$ homozygous subjects degrade LDL faster than normal $(11,12)$. Previous studies from this laboratory have examined VLDL, intermediate density lipoprotein (IDL), and LDL apo B metabolism in a number of genetically determined dyslipidemias. In particular, we found in patients with homozygous familial hypercholesterolemia that the LDL receptor was important not only in LDL catabolism but also in the processing of apo B-containing lipoproteins throughout much of the delipidation cascade from VLDL to LDL (13). Since apo E is important for lipoprotein receptor interaction, we surmised that structural and functional variation in this protein would modulate the metabolism of the lipoproteins within the entire ultracentrifuge flotation rate $\left(S_{f}\right)^{1} 0-400$ spectrum. To investigate this, we conducted VLDL turnover studies in groups of individuals homozygous for the three $\mathrm{E}$ variants. The results demonstrate the profound impact that this polymorphism has on apo B metabolism.

1. Abbreviations used in this paper: $\mathrm{FCR}$, fractional catabolic rate; FH, familial hypercholesterolemia; $S_{f}$, ultracentrifuge flotation rate; TMU, tetramethylurea. 


\section{Methods}

Subjects. The study participants were selected from individuals who attended a coronary screening program in health centers in Glasgow. The Institute of Biochemistry received samples for cholesterol assay as part of the screen and those in which the level lay in the range of 5.0-6.2 $\mathrm{mmol} / \mathrm{liter}(195-240 \mathrm{mg} / \mathrm{dl})$ were subjected to apo E phenotyping using the isoelectric focusing/immunoblotting technique described below. Subjects who were found to be homozygous for the presence of apo $\mathrm{E}_{2}(n=4)$, apo $\mathrm{E}_{3}(n=5)$, or apo $\mathrm{E}_{4}(n=5)$ were recruited for the study. For ease of presentation throughout this report subjects are referred to as the $E_{2}, E_{3}$, or $E_{4}$ group to denote phenotypically determined homozygosity for the $E_{2}, E_{3}$, or $E_{4}$ alleles (14). They were screened for cardiological, renal, endocrine, hepatic, or metabolic disease by routine clinical examination and biochemical testing. Age distribution and body weight index were similar in the three study groups. Each individual's dietary intake was recorded over a 7-d period and this was analyzed for the percent contribution of calories derived from protein, carbohydrates and fat $(15) .^{2}$ Although daily energy intake (kilocalorie per day) varied considerably, approximately in proportion to

2. Intake was analyzed by using the computer program MICRODIET (Department of Computer Sciences, Salford University, Salford, UK). differences in body frame, the composition of food was virtually the same in the three groups.

Plasma lipid and lipoprotein levels of study participants given in Table I were measured according to the Lipid Research Clinics protocol (16).

Apo E phenotyping. Apo $\mathrm{E}$ isoforms were detected as described by Menzel et al. (5) and Havekes et al. (6). $10 \mu \mathrm{l}$ of plasma were delipidated, redissolved in $6 \mathrm{M}$ urea containing $0.1 \mathrm{M}$ Tris, $\mathrm{pH} 10.0,5 \%$ $\beta$-mercaptoethanol, and $1 \%$ sodium decyl sulfate and applied to a vertical polyacrylamide slab gel of $5 \%(\mathrm{wt} / \mathrm{vol})$ acrylamide in $8 \mathrm{M}$ urea containing $1 \%$ ampholyte ( $\mathrm{pH}$ range 4-6). The cathode buffer was 0.2 $\mathrm{M} \mathrm{NaOH}$ and the anode buffer $0.1 \mathrm{M} \mathrm{H}_{3} \mathrm{PO}_{4}$. Isoelectric focusing was carried out at $3 \mathrm{~W}$ per gel for $16 \mathrm{~h}$. Transfer by electrophoresis from the acrylamide slab gels to nitrocellulose membranes was performed as described by Towbin et al. (17). The transfer buffer contained $0.2 \mathrm{M}$ glycine, $0.025 \mathrm{M}$ Tris, and $20 \%$ methanol and the current applied was $0.4 \mathrm{~A}$ for $3 \mathrm{~h}$. Apo $\mathrm{E}$ isoforms bound to the membrane were visualized by immunostaining using a monoclonal or polyclonal apo E-specific antibody and an appropriate IgG-binding second antibody linked to horseradish peroxidase.

Lipoprotein isolation and labeling. The methods for preparation of tracer VLDL subfractions VLDL $_{1}\left(S_{\mathrm{f}} 60-400\right)$ and $\operatorname{VLDL}_{2}\left(\mathrm{~S}_{\mathrm{f}} 20-60\right)$, have been described in detail in previous publications (18). Briefly, 250 $\mathrm{ml}$ of plasma was removed by plasmapheresis from subjects who had been fasted overnight and total VLDL of $d<1.006 \mathrm{~g} / \mathrm{ml}\left(\mathrm{S}_{\mathrm{f}} 20-400\right)$

Table I. Plasma Lipid and Lipoprotein Levels in $E_{2}, E_{3}$, and $E_{4}$ Subjects

\begin{tabular}{|c|c|c|c|c|c|c|c|c|c|}
\hline Subject & Sex & Age & Weight & $\begin{array}{c}\text { Total } \\
\text { triglyceride }\end{array}$ & $\begin{array}{c}\text { Total } \\
\text { cholesterol }\end{array}$ & $\begin{array}{c}\text { VLDL } \\
\text { cholesterol }\end{array}$ & $\begin{array}{c}\text { LDL } \\
\text { cholesterol }\end{array}$ & $\begin{array}{c}\text { HDL } \\
\text { cholesterol }\end{array}$ & $\begin{array}{l}\text { VLDL cholesterol/plasma } \\
\text { triglyceride ratio }\end{array}$ \\
\hline & & $y r$ & $k g$ & & & $\mathrm{mmol} / \mathrm{liter}$ & & & \\
\hline \multicolumn{10}{|l|}{$E_{2 / 2}$} \\
\hline 1 & $\mathbf{M}$ & 47 & 74.0 & $1.60 \pm 0.79$ & $4.88 \pm 0.13$ & $1.03 \pm 0.64$ & $2.43 \pm 0.43$ & $1.42 \pm 0.19$ & 0.64 \\
\hline 2 & $F$ & 39 & 47.0 & $1.80 \pm 0.27$ & $4.85 \pm 0.35$ & $1.07 \pm 0.10$ & $2.45 \pm 0.26$ & $1.33 \pm 0.08$ & 0.59 \\
\hline 3 & $F$ & 45 & 63.0 & $1.85 \pm 0.27$ & $6.14 \pm 0.83$ & $1.41 \pm 0.47$ & $3.25 \pm 0.49$ & $1.48 \pm 0.23$ & 0.76 \\
\hline 4 & $F$ & 57 & 53.0 & $1.64 \pm 0.08$ & $5.96 \pm 0.76$ & $1.25 \pm 0.24$ & $3.25 \pm 0.59$ & $1.48 \pm 0.21$ & 0.76 \\
\hline Mean \pm SD & \multicolumn{2}{|c|}{$\begin{array}{c}\mathrm{mmol} / \mathrm{liter} \\
(\mathrm{mg} / \mathrm{dl})\end{array}$} & & $\begin{array}{l}1.72 \pm 0.10 \\
(151 \pm 9) \\
\end{array}$ & $\begin{array}{l}5.46 \pm 0.60 \\
(211 \pm 23) \\
\end{array}$ & $\begin{array}{c}1.19 \pm 0.15^{*} \\
(46 \pm 6)\end{array}$ & $\begin{array}{l}2.84 \pm 0.40 \\
(110 \pm 15) \\
\end{array}$ & $\begin{array}{c}1.43 \pm 0.06 \\
(55 \pm 2) \\
\end{array}$ & $\begin{array}{c}0.69 \pm 0.07^{\ddagger} \\
(0.30 \pm 0.03) \\
\end{array}$ \\
\hline & & $y r$ & $\mathrm{~kg}$ & & & mmol/liter & & & \\
\hline \multicolumn{10}{|l|}{$E_{3 / 3}$} \\
\hline 5 & $\mathbf{M}$ & 36 & 71.0 & $1.71 \pm 0.38$ & $4.96 \pm 0.54$ & $0.79 \pm 0.21$ & $3.14 \pm 0.35$ & $1.01 \pm 0.13$ & 0.46 \\
\hline 6 & $\mathbf{M}$ & 43 & 86.0 & $2.55 \pm 0.71$ & $6.23 \pm 0.79$ & $1.02 \pm 0.25$ & $4.09 \pm 0.50$ & $1.36 \pm 0.19$ & 0.40 \\
\hline 7 & $\mathbf{M}$ & 46 & 89.0 & $1.09 \pm 0.13$ & $5.76 \pm 0.22$ & $0.61 \pm 0.14$ & $3.96 \pm 0.17$ & $1.19 \pm 0.08$ & 0.56 \\
\hline 8 & $F$ & 40 & 71.0 & $0.95 \pm 0.06$ & $4.97 \pm 0.32$ & $0.35 \pm 0.08$ & $2.76 \pm 0.17$ & $1.86 \pm 0.12$ & 0.37 \\
\hline 9 & $\mathbf{F}$ & 44 & 76.0 & $2.17 \pm 0.29$ & $5.63 \pm 0.35$ & $0.97 \pm 0.21$ & $3.74 \pm 0.14$ & $1.20 \pm 0.05$ & 0.45 \\
\hline Mean \pm SD & \multicolumn{2}{|c|}{$\begin{array}{c}\mathrm{mmol} / \mathrm{liter} \\
(\mathrm{mg} / \mathrm{dl})\end{array}$} & & $\begin{array}{l}1.69 \pm 0.56 \\
(148 \pm 49)\end{array}$ & $\begin{array}{l}5.51 \pm 0.49 \\
(213 \pm 19)\end{array}$ & $\begin{array}{c}0.75 \pm 0.25 \\
(29 \pm 10)\end{array}$ & $\begin{array}{l}3.54 \pm 0.51 \\
(137 \pm 20)\end{array}$ & $\begin{array}{c}1.32 \pm 0.29 \\
(51 \pm 11)\end{array}$ & $\begin{array}{c}0.45 \pm 0.06 \\
(0.20 \pm 0.03)\end{array}$ \\
\hline & & $y r$ & $\mathrm{~kg}$ & & & mmol/liter & & & \\
\hline$E_{4 / 4}$ & & & & & & & & & \\
\hline 10 & $\mathbf{M}$ & 29 & 85.0 & $2.00 \pm 0.75$ & $6.55 \pm 1.00$ & $1.08 \pm 0.54$ & $4.37 \pm 0.83$ & $1.10 \pm 0.22$ & 0.54 \\
\hline 11 & $\mathbf{F}$ & 41 & 62.0 & $1.49 \pm 0.28$ & $6.74 \pm 0.35$ & $0.61 \pm 0.23$ & $4.66 \pm 0.41$ & $1.39 \pm 0.19$ & 0.41 \\
\hline 12 & $\mathbf{M}$ & 45 & 79.0 & $2.01 \pm 0.59$ & $6.19 \pm 0.34$ & $0.99 \pm 0.50$ & $3.96 \pm 0.20$ & $1.23 \pm 0.14$ & 0.49 \\
\hline 13 & $\mathrm{~F}$ & 29 & 50.0 & $0.90 \pm 0.27$ & $5.66 \pm 0.40$ & $0.59 \pm 0.28$ & $3.35 \pm 0.49$ & $1.73 \pm 0.09$ & 0.66 \\
\hline 14 & $\mathbf{F}$ & 36 & 48.0 & $0.93 \pm 0.18$ & $5.33 \pm 0.46$ & $0.32 \pm 0.14$ & $3.45 \pm 0.44$ & $1.56 \pm 0.11$ & 0.34 \\
\hline Mean \pm SD & $\begin{array}{r}m m o \\
(m g\end{array}$ & $\begin{array}{l}\text { liter } \\
\text { dl) }\end{array}$ & & $\begin{array}{l}1.47 \pm 0.49 \\
(129 \pm 43)\end{array}$ & $\begin{array}{l}6.09 \pm 0.53 \\
(236 \pm 21)\end{array}$ & $\begin{array}{c}0.72 \pm 0.30 \\
(28 \pm 12)\end{array}$ & $\begin{array}{l}3.96 \pm 0.51 \\
(153 \pm 20)\end{array}$ & $\begin{array}{l}1.40 \pm 0.23 \\
(54 \pm 9)\end{array}$ & $\begin{array}{c}0.49 \pm 0.11 \\
(0.22 \pm 0.05)\end{array}$ \\
\hline
\end{tabular}

${ }^{*}$ Significantly different from $\mathrm{E}_{3}$ group $P<0.05 ;{ }^{\ddagger} P<0.01$ by Student's $t$ test. 
isolated by centrifugation for $18 \mathrm{~h}$ at $36,000 \mathrm{rpm}$ and $10^{\circ} \mathrm{C}$ in a Ti60 rotor (Beckman Instruments, Inc., Palo Alto, CA). The supernatant was harvested by suction and used for preparation of the subfractions. The VLDL solution was adjusted to a density of $1.118 \mathrm{~kg} /$ liter by the addition of $\mathrm{NaCl}(0.34 \mathrm{~g}$ per $2 \mathrm{ml}$ of solution) and layered in a SW40 rotor tube (Beckman Instruments, Inc.). A six-step gradient from $1.0988-1.0588 \mathrm{~kg} /$ liter was constructed above the sample and centrifugation carried out at $23^{\circ} \mathrm{C}$ to separate sequentially $\operatorname{VLDL}_{1}(1 \mathrm{~h} 38 \mathrm{~min}$, $39,000 \mathrm{rpm})$ and $\mathrm{VLDL}_{2}(15 \mathrm{~h} 41 \mathrm{~min} ; 18,500 \mathrm{rpm})$. The subfractions were labeled with ${ }^{131} I$ and ${ }^{125} I$, respectively, by a modification of the iodine monochloride method (19) and sterilized by filtration through an $\mathbf{0 . 4 5}$ micron filter (Millipore, Molsheim, France).

Turnover protocol. Subjects were fasted from 8 p.m. and injected with autologous trace-labeled ${ }^{131} \mathrm{I}_{-}-\mathrm{VDL}_{1}$ and ${ }^{125} \mathrm{I}-\mathrm{VLDL} \mathrm{L}_{2}$ at $8.00 \mathrm{a}$.m. on the following day. The tracers ( $50 \mu \mathrm{Ci}$ of each iodine isotope) were administered within $72 \mathrm{~h}$ of blood being withdrawn for their preparation. During the first day of the turnover to minimize chylomicron production the volunteers were fasted until 6.00 p.m. Plasma samples were obtained at frequent intervals over the $72 \mathrm{~h}$ after injection and then daily in the fasting state for $14 \mathrm{~d}$. The apo B-containing lipoproteins VLDL ${ }_{1}\left(S_{\mathrm{f}} 60-400\right), \mathrm{VLDL}_{2}\left(\mathrm{~S}_{\mathrm{f}} 20-60\right)$, IDL $\left(\mathrm{S}_{\mathrm{f}} 12-20\right)$, and LDL $\left(\mathrm{S}_{\mathrm{f}} 0-12\right)$ were prepared by a modification (13) of the cumulative gradient ultracentrifugation (20). From these apo B was isolated by tetramethylurea (TMU) precipitation (21) and its specific activity was determined by radioactivity counting and protein determination (22).

The apo B pool circulating with each of these lipoprotein fractions was determined by replicate analyses of plasma samples collected intermittently throughout the turnover study. Correction was made for possible B protein loss during TMU precipitation by comparing the apo B recovered at the end of the procedure with the values calculated as the difference between total and TMU-soluble (apo E and C) protein contents (21). The composition of each fraction was determined by assay of total and esterified cholesterol, triglyceride, phospholipid, and protein (23). Protein determinations were performed with the addition of sodium dodecyl sulfate to the Biuret reagent (22).

Subjects received potassium iodate in tablet form $(180 \mathrm{mg} / \mathrm{d})$ for $3 \mathrm{~d}$ before and $1 \mathrm{mo}$ after injection to block thyroidal sequestration of radioactive iodine released by catabolism.

Kinetic analysis. The radioactivity associated with the apo B protein present in each lipoprotein fraction was calculated from the apo B specific activities and the individual pool sizes. These were expressed as a percentage of the total apo B radioactivity (i.e., $\mathrm{VLDL}_{1}$ plus $\mathrm{VLDL}_{2}$, IDL, and LDL) present in the plasma $10 \mathrm{~min}$ after injection and the resulting values were used to construct decay curves which were analyzed by the SAAM 30 (24) multicompartmental modeling program. The metabolic model employed (Fig. 1) was basically the same as de-

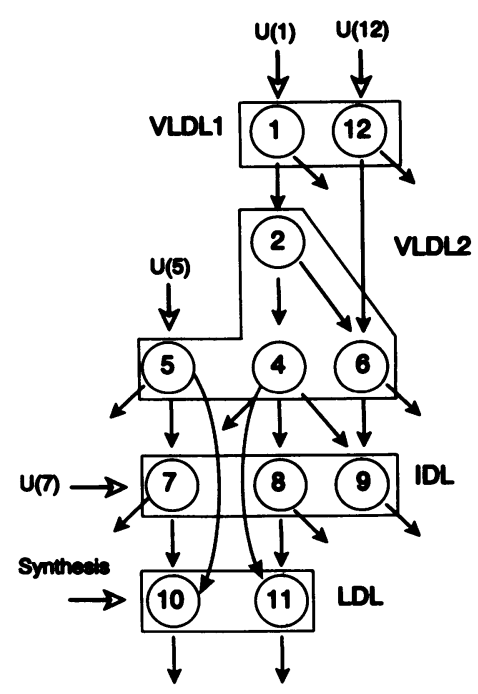

Figure 1. Multicompartmental model for apo B metabolism in $\mathrm{VLDL}_{1}\left(\mathrm{~S}_{\mathrm{f}}\right.$ 60-400), $\mathrm{VLDL}_{2}\left(\mathrm{~S}_{\mathrm{f}} 20-\right.$ $60)$, IDL $\left(S_{\mathrm{f}} 12-20\right)$, and $\operatorname{LDL}\left(\mathrm{S}_{\mathrm{f}} 0-12\right) . \mathrm{U}_{1}, \mathrm{U}_{5}, \mathrm{U}_{7}$, and $U_{12}$ represent de novo input of apo $B$ into $\mathrm{VLDL}_{1}$, VLDL $_{2}$, and IDL. Synthesis into the LDL density interval was calculated as the difference between the absolute catabolic rate of apo $B$ in this fraction (observed mass $\times$ overall FCR) and the input from $\mathrm{VLDL}_{2}$ and IDL. scribed elsewhere (13) with the addition of a second subcompartment (compartment 12) in $\mathrm{VLDL}_{1}$ to account for the second exponential seen in $\mathrm{E}_{2}$ homozygotes. Its main features are as follows: $(a)$ apo $\mathrm{B}$ synthetic input occurs at the level of $\mathrm{VLDL}_{1}, \mathrm{VLDL}_{2}$, and, where indicated, IDL and LDL; (b) VLDL is delipidated in a stepwise manner following the concept of Berman et al. (25); (c) slowly catabolized remnant subpopulations are present in $\mathrm{VLDL}_{2}$ (compartment 6) and IDL (compartment 9); (d) parallel processing pathways exist leading from $\mathrm{VLDL}_{2}$ through IDL to LDL.

Rate constants were determined and in combination with B protein pool sizes were used to calculate flux rates and steady-state synthetic inputs. The rate constants, fluxes, and apo $B$ masses were compared in the $E_{2}, E_{3}$, and $E_{4}$ homozygotes by Student's $t$ test and Mann-Whitney nonparametric test.

Ethical consideration. All subjects participating in the study gave informed consent. The study met the requirements of the Ethical Committee of the Glasgow Royal Infirmary.

\section{Results}

The subjects for this study were selected from coronary screening clinic attendees whose plasma cholesterol at the initial visit fell in the range 5.0-6.2 mmol/liter. Mean values for total plasma cholesterol and triglyceride (Table I) in the three groups did not differ significantly from each other or from the population means $( \pm 1 \mathrm{SD})$ for these lipids of $5.8 \pm 1.2$ and $1.8 \pm 1.4$ $\mathrm{mmol} /$ liter, respectively. Using this selection process we attempted to minimize the effect that gross perturbations in plasma lipid levels would have on apo B kinetics. The distribution of cholesterol in the lipoprotein fractions, however, was characteristically different in the groups. VLDL cholesterol was significantly higher and LDL cholesterol lower in $\mathrm{E}_{2}$ vs. $\mathrm{E}_{3}$ homozygotes. Likewise, the VLDL cholesterol/plasma triglyceride ratio was increased in the $E_{2}$ individuals. In this small series there was no significant difference in plasma lipoprotein levels between $E_{3}$ and $E_{4}$ homozygotes, although LDL cholesterol was moderately elevated in the latter as might be expected (3). HDL cholesterol was the same in all three groups. These perturbations in lipid levels were reflected in the distribution of apo $B$ in the four lipoprotein fractions prepared by cumulative ultracentrifugation (Table II). Total apo B concentration, which was calculated as the sum of the apoprotein levels observed in $\mathrm{VLDL}_{1}, \mathrm{VLDL}_{2}$, IDL, and LDL, was markedly decreased in $\mathrm{E}_{2}$ homozygotes. This was due to a much reduced LDL apo $B$ level, which was approximately a third of that seen in $E_{3}$ subjects. $V_{L D L}$ apo $B$ in contrast was elevated in the $E_{2}$ compared with the $E_{3}$ group, whereas $V_{L D L}$ and IDL apo $B$ concentrations were similar. Individuals in the $E_{4}$ group had $\mathrm{VLDL}_{1}, \mathrm{VLDL}_{2}$, and IDL apo $B$ levels that were close to those seen in $E_{3}$ subjects, although there was a tendency for LDL apo $B$ to be higher in $E_{4}$ and the IDL/LDL ratio differed across all three groups $\left(\mathrm{E}_{2} 0.63 \pm 0.15, \mathrm{E}_{3} 0.16 \pm 0.016, \mathrm{E}_{2}\right.$ vs. $\mathrm{E}_{3} P<0.05$ by $t$ test; $\mathrm{E}_{4} 0.13 \pm 0.019, \mathrm{E}_{3}$ vs. $\mathrm{E}_{4} P<0.05$ by $t$ test).

The composition of the four apo B-containing lipoprotein fractions is given in Table III. Compared with $\mathrm{E}_{3}$ individuals, those with $\mathrm{E}_{2}$ showed a high unesterified cholesterol content in $\mathrm{VLDL}_{1}$ and an enrichment of cholesteryl ester at the expense of triglyceride in $\mathrm{VLDL}_{2}$. The percentage of free cholesterol in LDL was decreased in $\mathrm{E}_{2}$ homozygotes, and in this lipoprotein fraction there was also a graded decrease in triglyceride content comparing $\mathrm{E}_{2}$ with $\mathrm{E}_{3}$ and $\mathrm{E}_{4}$.

Apo B kinetic studies. The metabolic behavior of apo B in $\mathrm{VLDL}_{1}, \mathrm{VLDL}_{2}$, IDL, and LDL after simultaneous injection 
Table II. Apo B Concentrations in $E_{2}, E_{3}$, and $E_{4}$ Subjects

\begin{tabular}{cccccc}
\hline Subject & VLDL $_{1}$ & VLDL & IDL & LDL & Total Apo B \\
\hline \multicolumn{5}{c}{$m g / d l$} \\
$\mathrm{E}_{2 / 2}$ & \multicolumn{5}{c}{} \\
1 & 1.3 & 7.6 & 7.1 & 17.0 & 33 \\
2 & 2.8 & 9.5 & 13.4 & 21.3 & 47 \\
3 & 3.8 & 7.6 & 16.8 & 24.8 & 53 \\
4 & 2.6 & 9.5 & 15.1 & 19.8 & 47 \\
Mean \pm SD & $2.6 \pm 0.9$ & $8.6 \pm 1.0^{*}$ & $13.1 \pm 3.7$ & $20.7 \pm 3.2^{*}$ & $45 \pm 8^{*}$ \\
$\mathrm{E}_{3 / 3}$ & & & & & \\
5 & 3.3 & 6.3 & 8.7 & 57.8 & 76 \\
6 & 2.4 & 7.3 & 13.8 & 86.6 & 110 \\
7 & 3.7 & 5.8 & 11.3 & 76.3 & 97 \\
8 & 1.8 & 2.6 & 8.1 & 50.5 & 63 \\
9 & 4.9 & 7.5 & 12.6 & 66.0 & 91 \\
Mean \pm SD & $3.2 \pm 1.1$ & $5.9 \pm 2.0$ & $10.9 \pm 2.2$ & $67.4 \pm 14.4$ & $87 \pm 18$ \\
& & & & & \\
$\mathrm{E}_{4 / 4}$ & & & & & \\
10 & 4.1 & 7.5 & 13.6 & 82.8 & 108 \\
11 & 1.8 & 4.6 & 13.3 & 103.3 & 123 \\
12 & 4.6 & 5.0 & 8.1 & 58.3 & 76 \\
13 & 1.3 & 2.9 & 7.7 & 64.1 & 76 \\
14 & 0.2 & 3.5 & 10.1 & 88.1 & 102 \\
Mean \pm SD & $2.4 \pm 1.7$ & $4.7 \pm 1.6$ & $10.6 \pm 2.5$ & $79.3 \pm 16.4$ & $97 \pm 18$ \\
& & & & & \\
\hline
\end{tabular}

* Significantly different from $\mathrm{E}_{3}$ group, $P<0.02$ by Student's $t$ test.

of $\mathrm{VLDL}_{1}$ and $\mathrm{VLDL}_{2}$ tracers is shown in Fig. 2. In order to examine intergroup differences more closely, the observed data at each time point were averaged within group and are presented as a mean and standard error for the $E_{2}, E_{3}$, and $E_{4}$ subjects. Individual decay curves and apo $B$ masses were used in multicompartmental modeling to generate the kinetic parameters given in Tables IV and $\mathrm{V}$.

$\mathrm{VLDL}_{1}$ apo $\mathrm{B}$ radioactivity was cleared rapidly from the plasma of $\mathrm{E}_{3}$ and $\mathrm{E}_{4}$ homozygotes (Fig. 2 a). The decay curve was monoexponential and only $\sim 1 \%$ remained at the last time point on the first day, $14 \mathrm{~h}$ after injection. Clearance of this lipoprotein was slower in $E_{2}$ subjects with $\sim 10 \%$ remaining at $14 \mathrm{~h}$. The decay curve in the last group was biexponential containing a slow component which accounted for up to $10 \%$ of the apo B present in the $\mathrm{VLDL}_{1}$ tracer. This feature necessitated the addition to the model of a second compartment (compartment 12) in $\mathrm{VLDL}_{1}$ (Fig. 1). $\mathrm{VLDL}_{1}$ apo $\mathrm{B}$ appeared in $\mathrm{VLDL}_{2}$ with a peak radioactivity $\sim 5 \mathrm{~h}$ after injection in all subjects (Fig. $2 b$ ). Transfer of $\mathrm{VLDL}_{1}$ to $\mathrm{VLDL}_{2}$ was greater and catabolism of apo $B$ from $\mathrm{VLDL}_{2}$ was slower in $\mathrm{E}_{2}$ compared with $E_{3}$ and $E_{4}$ subjects. The latter was true whether label in this fraction was introduced directly as a $\mathrm{VLDL}_{2}$ tracer or derived from $\mathrm{VLDL}_{1}$.

The metabolism of IDL derived from both tracers (Fig. 2 c) was similar in all three groups. Radioactivity peaked at 8-10 h and decayed in a multiexponential fashion, slightly faster in $E_{3}$ than in $E_{2}$ or $E_{4}$ subjects. Substantial differences however were observed in the metabolic behavior of LDL apo B. Peak radioactivity values of $20 \%$ for the $\mathrm{VLDL}_{1}$ apo $\mathrm{B}$ tracer and $\sim 35 \%$ for the $V_{L D L}$ apo $B$ tracer were observed in LDL for $E_{3}$ and $E_{4}$ homozygotes. In contrast, $<5 \%$ and $\sim 12 \%$ of apo $B$ radioactivity derived from the $\mathrm{VLDL}_{1}$ and $\mathrm{VLDL}_{2}$ tracers, respectively, was seen in the LDL fraction of $E_{2}$ subjects. The decay curve for LDL apo $B$ in $E_{3}$ homozygotes appeared to decline more sharply than that for the $\mathrm{E}_{4}$ group, particularly over the first $5 \mathrm{~d}$ of the turnover.

There was little difference in $\mathrm{VLDL}_{1}$ apo B pool size in the three groups (Table IV $a$ ) in concordance with their similar plasma triglyceride levels (Table I). Apo B in this flotation interval was synthesized at about $800 \mathrm{mg} / \mathrm{d}$ and cleared at a rate

Table III. Composition of Apo B-containing Lipoproteins in $E_{2}, E_{3}$, and $E_{4}$ Subjects

\begin{tabular}{|c|c|c|c|c|c|}
\hline & Free cholesterol & Cholesteryl ester & Triglyceride & Phospholipids & Protein \\
\hline & & & $g / 100 g$ & & \\
\hline \multicolumn{6}{|l|}{$\mathrm{VLDL}_{1}$} \\
\hline$E_{2 / 2}$ & $4.7 \pm 0.5^{* \neq}$ & $19.9 \pm 3.9$ & $50.9 \pm 4.2$ & $17.3 \pm 1.2$ & $7.2 \pm 1.2$ \\
\hline$E_{3 / 3}$ & $1.5 \pm 1.8$ & $16.2 \pm 3.2$ & $57.4 \pm 4.1$ & $15.4 \pm 2.6$ & $9.4 \pm 2.0$ \\
\hline$E_{4 / 4}$ & $3.6 \pm 1.7$ & $14.4 \pm 5.8$ & $57.0 \pm 4.3$ & $17.7 \pm 2.7$ & $7.5 \pm 1.0$ \\
\hline \multicolumn{6}{|l|}{$\mathrm{VLDL}_{2}$} \\
\hline$E_{2 / 2}$ & $8.6 \pm 1.4$ & $30.5 \pm 3.7^{\ddagger}$ & $27.5 \pm 5.2^{8}$ & $21.5 \pm 1.4$ & $12.0 \pm 1.4$ \\
\hline$E_{3 / 3}$ & $6.4 \pm 1.9$ & $22.4 \pm 4.3$ & $36.9 \pm 2.9$ & $20.4 \pm 2.3$ & $14.1 \pm 1.4$ \\
\hline$E_{4 / 4}$ & $7.0 \pm 2.2$ & $22.6 \pm 2.1$ & $34.8 \pm 2.8$ & $21.2 \pm 0.8$ & $14.5 \pm 0.9$ \\
\hline \multicolumn{6}{|l|}{ IDL } \\
\hline$E_{2 / 2}$ & $9.5 \pm 1.6$ & $38.3 \pm 2.2$ & $11.6 \pm 2.8$ & $23.7 \pm 1.0$ & $17.0 \pm 0.8$ \\
\hline $\mathrm{E}_{3 / 3}$ & $8.9 \pm 3.0$ & $35.6 \pm 4.7$ & $14.3 \pm 1.7$ & $22.1 \pm 1.7$ & $19.0 \pm 1.7$ \\
\hline$E_{4 / 4}$ & $9.4 \pm 2.5$ & $37.0 \pm 1.7$ & $11.4 \pm 2.0$ & $23.2 \pm 1.2$ & $19.0 \pm 1.4$ \\
\hline \multicolumn{6}{|l|}{ LDL } \\
\hline$E_{2 / 2}$ & $8.4 \pm 1.6^{\ddagger}$ & $38.2 \pm 1.9$ & $7.9 \pm 1.2^{\ddagger}$ & $22.8 \pm 0.7$ & $22.8 \pm 0.9$ \\
\hline$E_{3 / 3}$ & $11.6 \pm 1.6$ & $37.0 \pm 2.0$ & $6.0 \pm 0.9$ & $22.0 \pm 0.5$ & $23.4 \pm 1.4$ \\
\hline$E_{4 / 4}$ & $11.2 \pm 1.2$ & $36.5 \pm 0.7$ & $4.4 \pm 0.6^{\S}$ & $21.9 \pm 1.7$ & $26.0 \pm 2.4$ \\
\hline
\end{tabular}

${ }^{*}$ Mean $\pm 1 \mathrm{SD}$. Significantly different from $\mathrm{E}_{3}$ group, ${ }^{\ddagger} P<0.05,{ }^{8} P<0.02$ by Student's $t$ test. 


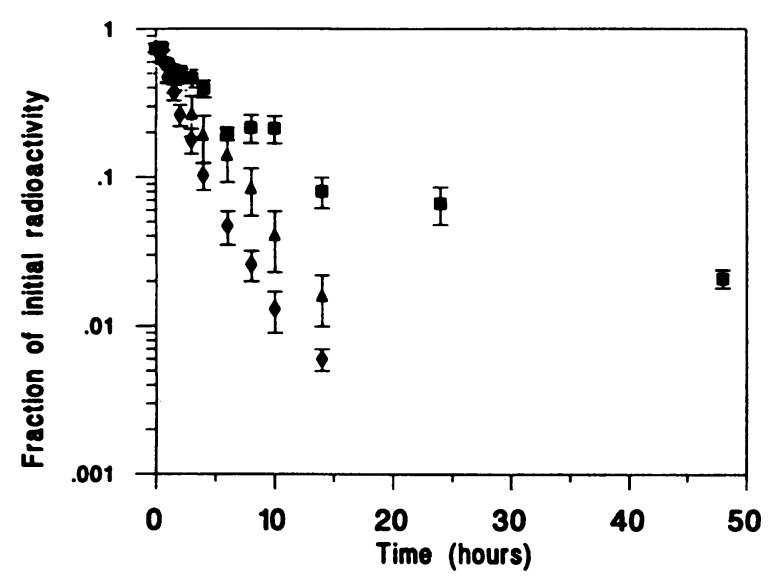

$2 b \quad 131$ VLDL2 apoB

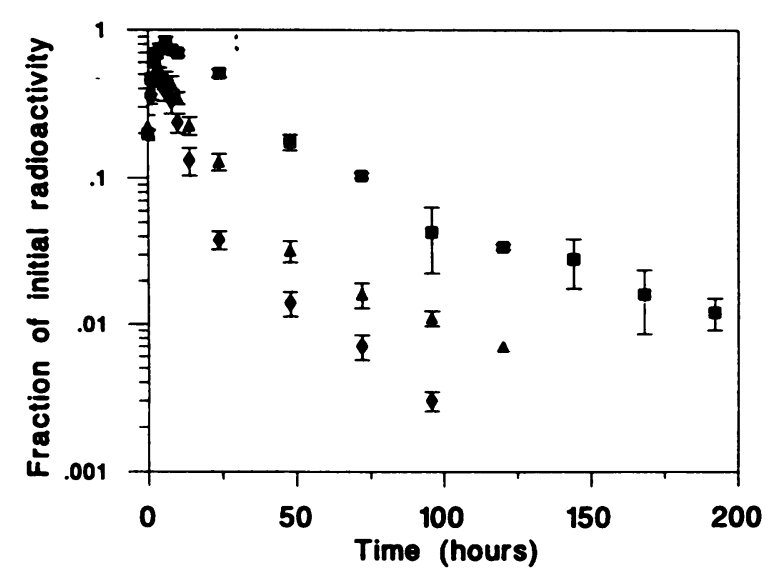

125 VLDL2 apoB

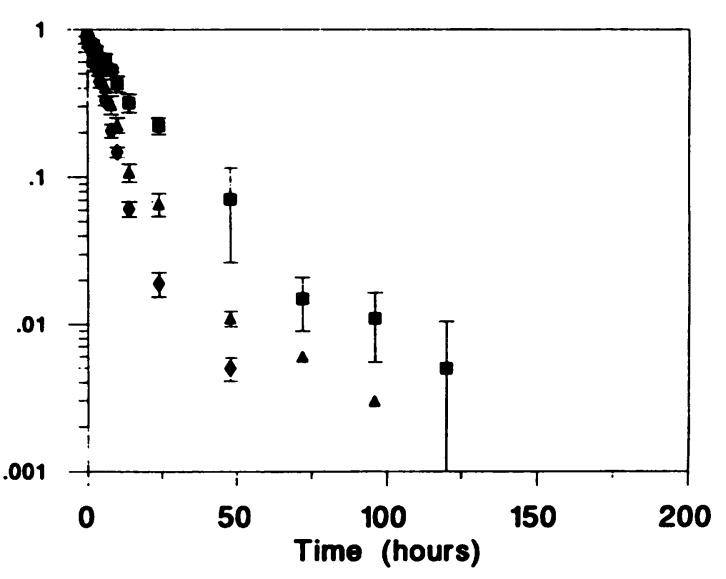

Figure 2. Apo B radioactivity decay curves in $(a) \mathrm{VLDL}_{1},\left(\right.$ b) $\mathrm{VLDL}_{2},(c) \mathrm{IDL}$, and (d) LDL (opposite page) in $\mathrm{E}_{2}, \mathrm{E}_{3}$, and $\mathrm{E}_{4}$ subjects. Tracers of ${ }^{131}{ }_{1-V L D L}$ and ${ }^{125}{ }^{1-V L D L} L_{2}$ were injected simultaneously and their metabolism was followed through IDL to LDL. The data were calculated for individual subjects and are here presented as a mean $\pm S E$ for each group: (๑) $E_{2},(\bullet) E_{3},(\Delta) E_{4}$.

of 10 pools/d in $E_{3}$ subjects. It had two metabolic fates, on average two-thirds were catabolized directly from plasma whereas the remainder was lipolysed to $\mathrm{VLDL}_{2}$. The results in $\mathrm{E}_{4}$ homozygotes did not differ significantly from those seen in the $E_{3}$ group. However, $E_{2}$ homozygotes exhibited low apo $B$ synthetic rates and greatly reduced direct catabolism of $\mathrm{VLDL}_{1}$ (Table IV $a$, Fig. $2 b$ ). It is noteworthy that the $\operatorname{VLDL}_{1}$ to $\mathrm{VLDL}_{2}$ transfer rate was not affected by apo $E$ phenotype. Approximately $10 \%$ of the $\mathrm{VLDL}_{1}$ apo $B$ mass in $\mathrm{E}_{2}$ subjects was placed in the slowly metabolized second compartment [M (12), Table $\mathrm{V}$ a]. Material from this pool was cleared directly from the plasma or delipidated to $\mathrm{VLDL}_{2}$. The mathematical model (Fig. 1) was constructed so that apo B from remnant compartment 12 in VLDL, when delipidated, appeared in the $\mathrm{VLDL}_{2}$ remnant pool (compartment 6).

Apo $E$ phenotype appeared not to influence the rate of input of apo $B$ into $\mathrm{VLDL}_{2}$ whether the material was derived from direct synthesis or from delipidation of $\mathrm{VLDL}_{1}$ (Table IV $b$ ). The overall pool size of $\mathrm{VLDL}_{2}$ apo B did not differ in the three groups although the remnant compartment (compartment 6$)$ was specifically increased in the $\mathrm{E}_{2}$ subjects $(P<0.02$ by Mann-Whitney test, Table V c). This was apparently due to increased diversion of apo B from the delipidation chain into the slowly metabolized compartment $\{$ cf. $L(6,2) /[L(4,2)$ $+\mathrm{L}(6,2)]$ in $E_{2}$ vs. $E_{3}$ and $E_{4}$ subjects in Table $\left.V b\right\}$ as well as a contribution of material derived from $\mathrm{VLDL}_{1}$ remnant catabolism [by L 6,12$)$, Table V a]. Direct catabolism of $\mathrm{VLDL}_{2}$ apo $B$ was reduced (although not significantly, $P=0.11$ ) in $\mathrm{E}_{2}$ homozygotes compared to $\mathrm{E}_{3}$ subjects (Table IV $b$ ) while on-going delipidation to IDL was the same in all three groups. In no subject was there a requirement for de novo apo B synthesis at the level of IDL (Table IV $c$ ); the plasma pool of IDL apo B which was $\sim 300-500 \mathrm{mg}$ in all subjects was derived entirely from $\mathrm{VLDL}_{2}$ catabolism. The metabolic fate of this fraction differed according to apo $E$ phenotype. The transfer rate of IDL to LDL was reduced significantly by $66 \%$ in the $\mathrm{E}_{2}$ group compared to $\mathrm{E}_{3}$ and $\mathrm{E}_{4}$ homozygotes. In contrast, direct IDL apo $B$ catabolism was increased in $\mathrm{E}_{2}$ subjects (Tables IV $c$ and V $d$ ). This redirection was found to be a feature of both parallel pathways of apo $\mathrm{B}$ delipidation [Table $\mathrm{V} d \mathrm{~L}(10,7), \mathrm{L}(11,8)$ ]. The differences in $\mathrm{E}_{4}$ vs. $\mathrm{E}_{3}$ subjects were not as dramatic. There was a tendency for reduced direct IDL apo $B$ catabolism in $E_{4}$ ho- 


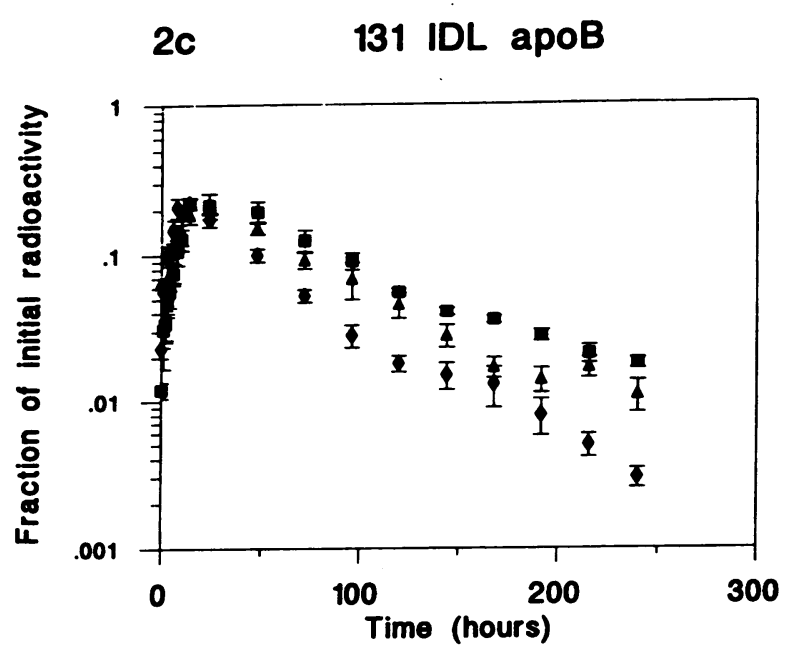

2d $131 \mathrm{LDL}$ apoB

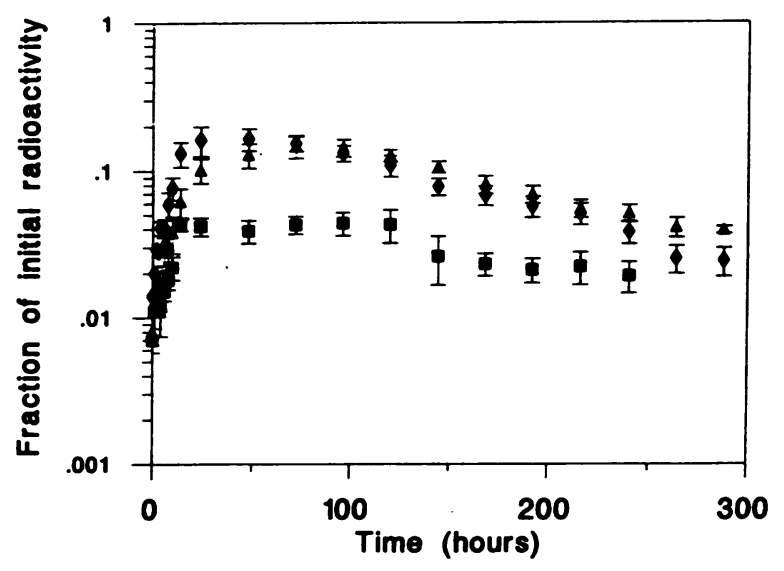

125 IDL apoB

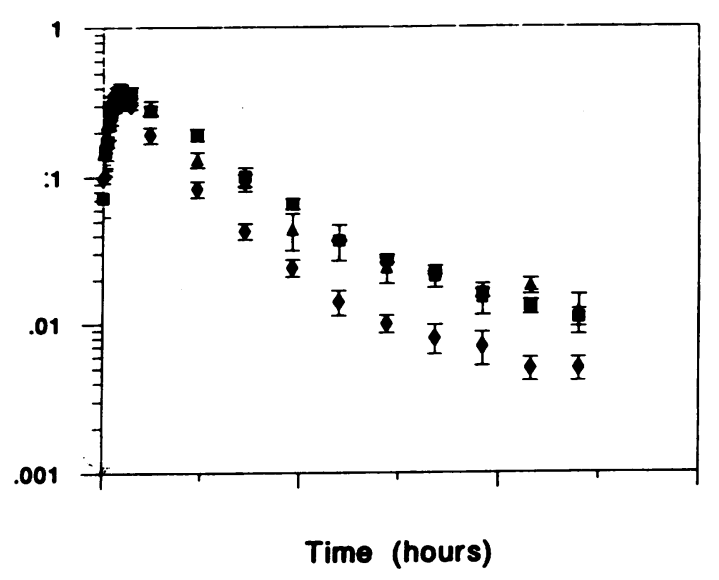

125 LDL apoB

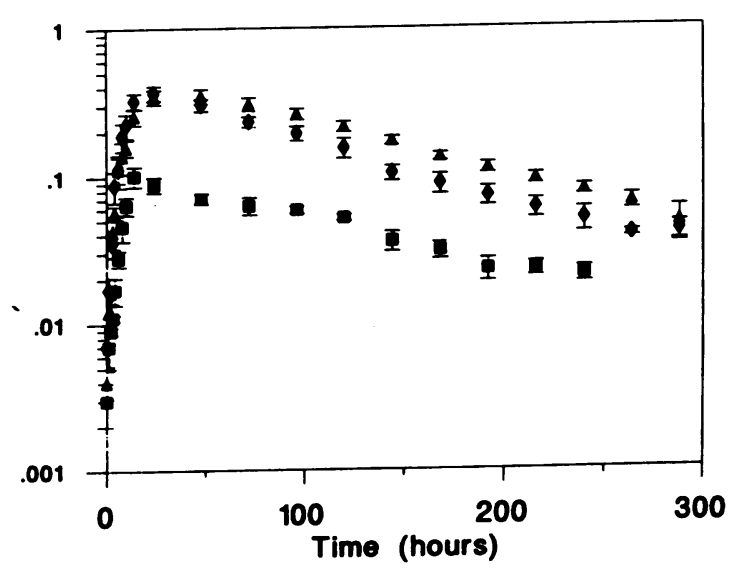

Figure 2 (Continued)

mozygotes (Table IV $c$ ). This can be seen in the individual fractional rates of delipidation and catabolism for compartments 7 and 8 in Table $\mathrm{V} d$. When the proportion of $\mathrm{VLDL}_{2}$ turnover in milligrams per day directed towards LDL apo B was calculated (i.e., LDL production/VLDL 2 synthesis, Tables IV $b$ and $d$ ), there was a clear gradation across the phenotypes. In $\mathrm{E}_{2}$ homozygotes $23 \pm 8 \%$ of $\mathrm{VLDL}_{2}$ apo $\mathrm{B}$ turnover was used to make LDL. This was significantly different from the $50 \pm 13 \%$ in $\mathrm{E}_{3}$ subjects $(P<0.02$ by Mann-Whitney test). Homozygotes for $\mathrm{E}_{4}$, however, converted significantly more VLDL $_{2}$ apo B to LDL $(70 \pm 14 \%, P<0.05)$ compared to the $\mathrm{E}_{3}$ group.

The main cause of the lower LDL apo B plasma concentration in $\mathrm{E}_{2}$ subjects was reduced synthesis from VLDL (Table IV d). Both LDL subcompartments (compartments 10 and 11) were reduced in mass compared to $\mathrm{E}_{3}$ (Table $\mathrm{V} e$ ). There was little direct synthesis of apo B in the LDL flotation interval of the $E_{2}$ group and the catabolic rate for the apoprotein was similar to that seen in $\mathrm{E}_{3}$ homozygotes. In $\mathrm{E}_{4}$ homozygotes the overall fractional catabolic rate (FCR) of LDL apo B was reduced by $23 \%$ (Table IV $d$ ) owing to a specific decrease in the elimination constant for the faster catabolized compartment 10 (Table $\mathrm{V} e$ ). In the majority of $\mathrm{E}_{2}$ and $\mathrm{E}_{3}$ individuals, $\mathrm{L}(0$,
10) exceeded $L(0,11)$ by $\sim 63 \%$, whereas in the $E_{4}$ group the rate of $\mathrm{LDL}$ apo $B$ catabolism from these two compartments was virtually identical. This is in keeping with the flat nature of the LDL apo B decay curve in $\mathrm{E}_{4}$ subjects (Fig. $2 d$ ).

\section{Discussion}

The polymorphism in the gene coding for apo $\mathrm{E}$ is the most important inherited trait modulating plasma cholesterol levels in the normal population (3). This study was designed to investigate the perturbations in apo B metabolism associated with homozygosity for the three common phenotypes, $E_{2}, E_{3}$, and $E_{4}$. Subjects were located during the screening of several thousand individuals for coronary risk factors. A decision was taken to select volunteers from those whose total plasma cholesterol levels on initial presentation were in a range $(5.0-6.2 \mathrm{mmol} /$ liter) that straddled the mean population value. By this approach we hoped to minimize any effect that gross differences in plasma lipid levels might have on apo B kinetics. Mean $( \pm 1$ $\mathrm{SD}$ ) cholesterol levels in subjects homozygous for apo $\mathrm{E}_{2}$, apo $E_{3}$, and apo $E_{4}$ in the whole screened population were $5.28 \pm 0.71,5.51 \pm 0.72$, and $5.93 \pm 1.18 \mathrm{mmol} /$ liter, respectively. There was no significant difference in plasma choles- 
Table IV. Apo B Metabolism in $E_{2}, E_{3}$, and $E_{4}$ Normolipidemic Subjects

\begin{tabular}{|c|c|c|c|c|c|c|c|c|c|c|c|}
\hline a. $\mathrm{VLDL}_{1}$ & \multicolumn{2}{|c|}{ Synthesis } & $\begin{array}{c}\text { Plasma } \\
\text { pool }\end{array}$ & $\begin{array}{c}\text { Direct } \\
\text { catabolism }\end{array}$ & $\begin{array}{l}\text { Transfer } \\
\text { to VLDL }\end{array}$ & c. IDL & $\begin{array}{c}\text { Direct } \\
\text { synthesis }\end{array}$ & $\begin{array}{c}\text { Flux from } \\
\text { VLDL }_{2}\end{array}$ & $\begin{array}{c}\text { Plasma } \\
\text { pool }\end{array}$ & $\begin{array}{c}\text { Direct } \\
\text { catabolism }\end{array}$ & $\begin{array}{l}\text { Transfer } \\
\text { to LDL }\end{array}$ \\
\hline & \multicolumn{2}{|c|}{$m g / d$} & $m g$ & \multicolumn{2}{|c|}{ pools/d } & & \multicolumn{2}{|c|}{$m g / d$} & $m g$ & \multicolumn{2}{|c|}{ pools/d } \\
\hline$E_{2 / 2}$ & & \multicolumn{6}{|l|}{$E_{2 / 2}$} \\
\hline 1 & \multicolumn{2}{|c|}{140} & 37 & 1.24 & 2.54 & 1 & 0 & 455 & 253 & 1.55 & 0.24 \\
\hline 2 & \multicolumn{2}{|c|}{396} & 54 & 2.57 & 4.76 & 2 & 0 & 370 & 330 & 0.70 & 0.42 \\
\hline 3 & \multicolumn{2}{|c|}{374} & 85 & 0.00 & 4.39 & 3 & 0 & 510 & 467 & 0.77 & 0.32 \\
\hline 4 & \multicolumn{2}{|c|}{338} & 50 & 1.92 & 4.84 & 4 & 0 & 334 & 309 & 0.73 & 0.34 \\
\hline Median & \multicolumn{2}{|c|}{$356^{* \pm}$} & 52 & $1.58^{* \ddagger}$ & 4.58 & Median & 0 & 413 & 320 & 0.75 & $0.33^{* *}$ \\
\hline$E_{3 / 3}$ & & & & $E_{3 / 3}$ & & & & & \\
\hline 5 & & & 67 & 4.17 & 5.16 & 5 & 0 & 621 & 241 & 0.76 & 1.80 \\
\hline 6 & \multicolumn{2}{|c|}{522} & 52 & 5.75 & 4.49 & 6 & 0 & 495 & 408 & 0.18 & 1.02 \\
\hline 7 & \multicolumn{2}{|c|}{1,288} & 97 & 10.79 & 2.48 & 7 & 0 & 517 & 358 & 0.26 & 1.17 \\
\hline 8 & \multicolumn{2}{|c|}{1,120} & 106 & 6.91 & 3.66 & 8 & 0 & 385 & 351 & 0.33 & 0.76 \\
\hline 9 & \multicolumn{2}{|c|}{819} & 47 & 14.73 & 2.71 & 9 & 0 & 189 & 174 & 0.37 & 0.68 \\
\hline Median & \multicolumn{2}{|c|}{819} & 67 & 6.91 & 3.66 & Median & 0 & 495 & 351 & 0.33 & 1.02 \\
\hline$E_{4 / 4}$ & \multirow{2}{*}{\multicolumn{2}{|c|}{894}} & & & & $E_{4 / 4}$ & & & & - & \\
\hline 10 & & & 107 & 5.36 & 2.99 & 10 & 0 & 593 & 442 & 0.41 & 0.94 \\
\hline 11 & \multicolumn{2}{|c|}{474} & 105 & 2.53 & 1.98 & 11 & 0 & 387 & 272 & 0.33 & 1.10 \\
\hline 12 & 5 & & 45 & 7.56 & 3.88 & 12 & 0 & 305 & 324 & 0.01 & 0.93 \\
\hline 13 & 29 & & 12 & 16.80 & 7.68 & 13 & 0 & 235 & 171 & 0.17 & 1.25 \\
\hline 14 & 14 & & 16 & 0.00 & 9.12 & 14 & 0 & 370 & 209 & 0.12 & 1.65 \\
\hline Median & 47 & & 45 & 5.36 & 3.88 & Median & 0 & 370 & 272 & 0.17 & 1.10 \\
\hline b. $\mathrm{VLDL}_{2}$ & $\begin{array}{c}\text { Direct } \\
\text { synthesis }\end{array}$ & $\begin{array}{c}\text { Flux from } \\
\text { VLDL }_{1}\end{array}$ & $\begin{array}{c}\text { Plasma } \\
\text { pool }\end{array}$ & $\begin{array}{c}\text { Direct } \\
\text { catabolism }\end{array}$ & $\begin{array}{c}\text { Transfer to } \\
\text { IDL and LDL }\end{array}$ & d. LDL & $\begin{array}{c}\text { Directs } \\
\text { synthesis }\end{array}$ & IDL & $\begin{array}{l}\text { ux from } \\
\text { and VLDL }\end{array}$ & $\begin{array}{c}\text { Plasma } \\
\text { pool }\end{array}$ & LDL FCR \\
\hline & & & $m g$ & & ols/d & & & $m g / d$ & & $m g$ & pools/d \\
\hline$E_{2 / 2}$ & & & & & & $E_{2 / 2}$ & & & & & \\
\hline 1 & 373 & 94 & 224 & 0.06 & 2.03 & 1 & 10 & & 61 & 507 & 0.14 \\
\hline 2 & 238 & 257 & 237 & 0.42 & 1.67 & 2 & 14 & & 165 & 460 & 0.39 \\
\hline 3 & 333 & 374 & 215 & 0.84 & 2.46 & 3 & 12 & & 164 & 650 & 0.27 \\
\hline 4 & 234 & 242 & 214 & 0.65 & 1.56 & 4 & 2 & & 106 & 450 & 0.24 \\
\hline Median & 284 & 250 & 220 & 0.54 & 1.85 & Median & $11^{* \neq}$ & & $135^{\ddagger}$ & $484^{\ddagger}$ & 0.26 \\
\hline$E_{3 / 3}$ & & & & & & $E_{3 / 3}$ & & & & & \\
\hline 5 & 301 & 346 & 160 & 0.18 & 3.88 & 5 & 0 & & 435 & 1,433 & 0.30 \\
\hline 6 & 761 & 229 & 231 & 2.14 & 2.14 & 6 & 233 & & 418 & 2,505 & 0.26 \\
\hline 7 & 500 & 241 & 199 & 0.92 & 2.81 & 7 & 10 & & 460 & 2,044 & 0.23 \\
\hline 8 & 280 & 388 & 218 & 1.15 & 1.93 & 8 & 153 & & 301 & 1,620 & 0.28 \\
\hline 9 & 203 & 127 & 69 & 2.14 & 2.74 & 9 & 183 & & 119 & 1,160 & 0.26 \\
\hline Median & 301 & 241 & 199 & 1.15 & 2.74 & Median & 153 & & 418 & 1,620 & 0.26 \\
\hline$E_{4 / 4}$ & & & & & & $E_{4 / 4}$ & & & & & \\
\hline 10 & 273 & 320 & 249 & 0.00 & 2.38 & 10 & 83 & & 415 & 2,490 & 0.20 \\
\hline 11 & 180 & 208 & 170 & 0.01 & 2.28 & 11 & 69 & & 299 & 1,750 & 0.21 \\
\hline 12 & 480 & 175 & 120 & 2.89 & 2.54 & 12 & 58 & & 305 & 2,588 & 0.14 \\
\hline 13 & 173 & 92 & 57 & 0.46 & 4.14 & 13 & 41 & & 214 & 1,274 & 0.20 \\
\hline 14 & 332 & 146 & 79 & 1.15 & 4.90 & 14 & 65 & & 360 & 1,770 & 0.24 \\
\hline Median & 273 & 175 & 120 & 0.46 & 2.54 & Median & 65 & & 304 & 1,770 & $0.20^{\ddagger}$ \\
\hline
\end{tabular}

* Differences between groups were assessed by the Mann-Whitney test. Significantly different from $\mathrm{E}_{3}$ group, ${ }^{\ddagger} P<0.02$. ${ }^{8}$ Direct synthesis in LDL was calculated as the difference between the total absolute catabolic rate (observed mass $\times$ overall FCR) and the input from VLDL and IDL.

terol and triglyceride in the three groups of this study (Table I), although the $E_{2}$ homozygotes displayed the characteristic dyslipidemia associated with this phenotype, i.e., cholesterol- enriched VLDL and low LDL levels. Apo B levels in this group were low (Table II) despite the similarity in total plasma cholesterol in $E_{2}$ and $E_{3}$ subjects owing to the higher cholesterol to 
apo $B$ ratios in $\mathrm{VLDL}_{1}$ and $\mathrm{VLDL}_{2}$ (Table III) and higher concentrations of $\mathrm{VLDL}_{2}$ and IDL particles in the circulation (Table II) of the former group.

Kinetics studies using tracers of radioiodinated $\mathrm{VLDL}_{1}$ and $\mathrm{VLDL}_{2}$ revealed marked differences in the metabolic behavior of apo $B$ in $E_{2}$ and $E_{3}$ homozygotes and more subtle distinctions between the $E_{3}$ and $E_{4}$ groups. For comparative purposes, $\mathrm{E}_{3}$ is taken as the norm since it represents the commonest variant in the population. The decay curves obtained for the four lipoprotein fractions had the general features observed in previous investigations $(13,18)$. Only a minor modification to the model (compartment 12, Fig. 1) was required to accommodate $\mathrm{VLDL}_{1}$ apo $\mathrm{B}$ kinetics in the $\mathrm{E}_{2}$ group. This model developed for normal and hypertriglyceridemic subjects has been used successfully to explain apo B kinetics in other genetically determined dyslipidemic conditions such as homozygous familial hypercholesterolemia (FH) and hepatic lipase deficiency $(13,26)$.

Apo $B$ metabolism in $E_{3}$ homozygotes. In $\mathrm{E}_{3}$ subjects most apo $B$ entered the system at the level of $\mathrm{VLDL}_{1}$. This material had two fates, catabolism and transfer to $\mathrm{VLDL}_{2}$ by delipidation. Direct removal of $\mathrm{VLDL}_{1}$ apo $B$ from the circulation has been noted in virtually all subjects examined with this technique. The pathway was previously found to be present in normal and homozygous FH subjects (13) and its activity was not affected by a chemical modification of the $\mathrm{VLDL}_{1}$ tracer designed to prevent the interaction of apo $B$ with LDL receptors (27). These findings appear to eliminate the LDL receptor as the agent responsible for this catabolic route and at present the mechanism of this process is unknown. Previous work indicates that lipoprotein lipase is the agent responsible for the $\mathrm{VLDL}_{1}$ to $\mathrm{VLDL}_{2}$ conversion. Tracer studies show delayed catabolism of large VLDL in lipoprotein lipase-deficient subjects (28), whereas $\mathrm{VLDL}_{1}$ transfer to $\mathrm{VLDL}_{2}$ occurs at a normal rate in hepatic lipase (26) and LDL receptor (13) deficiency. When the enzyme is deficient (i.e. in type I hyperlipidemia [29]) or inhibited in its action (30), large triglyceride-rich VLDL accumulate. Apo B entering VLDL 2 by direct synthesis and by lipolysis of $\mathrm{VLDL}_{1}$ in $\mathrm{E}_{3}$ subjects was rapidly and efficiently converted to IDL and LDL (Table IV $b$ ); a trivial amount entered the $\mathrm{VLDL}_{2}$ remnant pool (compartment 6 , Table $\mathrm{V}$ c). About half of the apo B passing through the delipidation cascade from $\mathrm{VLDL}_{2}$ to LDL was lost by direct catabolism probably via LDL receptors. These removal mechanisms are inhibited in homozygous FH (13) and blocked by chemical modification of apo B (27). LDL apo B was divided into two metabolically distinct pools to account for the observation that apo $B$ derived from VLDL $_{2}$ appeared and was cleared more rapidly than material derived from $\operatorname{VLDL}_{1}(13,18)$.

Apo $B$ metabolism in $E_{2}$ homozygotes. The metabolism of $\mathrm{VLDL}_{1}$ apo $B$ differed in $\mathrm{E}_{2}$ compared with $\mathrm{E}_{3}$ subjects in three aspects. First, the decay curve was biexponential probably as a result of the presence of chylomicron remnants. It has been shown that subjects homozygous or heterozygous for the apo $\mathrm{E}_{2}$ phenotype clear chylomicrons slowly and therefore remnants are likely to be present even after a 12-h fast $(9,10)$. Remnant accumulation is a hallmark of type III hyperlipidemia, and we noted that the VLDL $\mathrm{VL}_{1}$ apo $\mathrm{B}$ curves observed in the present $E_{2}$ group were qualitatively similar to those found previously in type III subjects (18). The slowly metabolized species in the $\mathrm{VLDL}_{1}$ fraction in the present study was esti- mated at $10 \%$ of the apo B mass but direct quantitation of B48 vs. $B 100$ in the tracer (a measure of chylomicron remnant content) was not performed. Secondly, the rate of $\mathrm{VLDL}_{1}$ apo $B$ synthesis was significantly reduced in comparison to the $E_{3}$ subjects. The reason for this is not clear although it is possible that impaired delivery of chylomicron lipid to the liver in $\mathrm{E}_{2}$ homozygotes causes that organ subsequently to secrete less triglyceride-rich VLDL. Thirdly, there was less direct catabolism of $\mathrm{VLDL}_{1}$ apo B. This pathway accounted for $25 \%$ of $\mathrm{VLDL}_{1}$ clearance compared with $65 \%$ in $\mathrm{E}_{3}$ subjects (Table IV a). As mentioned above this unknown mechanism of apo B catabolism operates in most normal and hyperlipidemic subjects. Its decreased activity in $\mathrm{E}_{2}$ homozygotes indicates that functional apo $\mathrm{E}$ may be required for it to proceed efficiently and raises the possibility that a receptor may be involved. It is unlikely that the classical LDL receptor has a substantial role in this regard since the pathway works as normal in FH (13). There is evidence that the recently discovered LDL receptor-related protein has apo E-binding properties (31) and is a candidate agent for mediating chylomicron remnant removal. If very large triglyceride-rich VLDL were catabolized in a similar fashion to chylomicrons, then this would explain the decreased removal in $E_{2}$ homozygotes. Indeed, in vitro apo $E_{2}$ shows impairment in binding to the LDL receptor-related protein (32).

Apo B synthesis into $\mathrm{VLDL}_{2}$ whether de novo or from VLDL $L_{1}$ occurred at the same rate in $E_{2}$ and $E_{3}$ subjects (Table IV $b$ ). More apo $\mathrm{B}$ passing through the delipidation chain in $\mathrm{E}_{2}$ homozygotes was diverted to remnants and the expansion of this presumably cholesteryl ester-rich population of particles in $\mathrm{VLDL}_{2}$ to $13 \%$ of total apo $\mathrm{B}$ mass (compared to $<2 \%$ in $\mathrm{E}_{3}$ subjects, Table $\mathrm{V} c$ ) explains the abnormal composition of this lipoprotein fraction in the $\mathrm{E}_{2}$ group (Table II). Surprisingly the catabolic rate of $V_{L D L}$ remnants $[L(9,6)$ and $L(0,6)$, Table $V]$ was not consistently reduced in our $E_{2}$ subjects. IDL formation and clearance occurred at approximately the same rate in $E_{2}$ and $E_{3}$ subjects. However, the metabolic fate of apo B differed greatly between them with a $66 \%$ reduction in the rate of LDL formation in the former. This difference was the principal cause of reduced LDL levels in $\mathrm{E}_{2}$ homozygotes. The data in Tables IV and $V$ indicate that in $E_{2}$ subjects the impaired IDL to LDL conversion is balanced by increased catabolism of the intermediate fraction: an observation that suggests that functional apo $\mathrm{E}$ is not required for effective IDL clearance. Direct removal of IDL probably occurs via LDL receptors since it is inhibited by 1,2-cyclohexanedione modification of the lipoprotein (27) and is depressed in homozygous FH (13). In fact, there was no inhibition of VLDL ${ }_{2}$, IDL or LDL clearance in our $E_{2}$ subjects suggesting either that it is apo $B$ that acts as the ligand for receptors in these lipoproteins fractions (as is found in vitro $[33,34])$ or that an increase in receptor activity more than compensates for the reduced affinity of apo $\mathrm{E}_{2}$ for the receptor. The reason why direct IDL catabolism is favored over conversion to LDL in $\mathrm{E}_{2}$ homozygotes is unknown. The phenomenon was recorded previously in our study of the effects of bezafibrate on apo B metabolism in type III hyperlipidemic subjects (35). These were apo $E_{2}$ homozygotes with elevated lipid levels that were corrected by bezafibrate therapy. The mean on-therapy concentrations of plasma cholesterol, triglyceride, VLDL, LDL, and HDL cholesterol were 5.87, 2.12, 1.63, 2.79, and $1.46 \mathrm{mmol} /$ liter, respectively; values close to those seen in our normolipemic $\mathrm{E}_{2}$ group (Table I). Apo B kinetics in the type III 
Table V. Computed Masses and Rate Constants in $E_{2}, E_{3}$, and $E_{4}$ Subjects

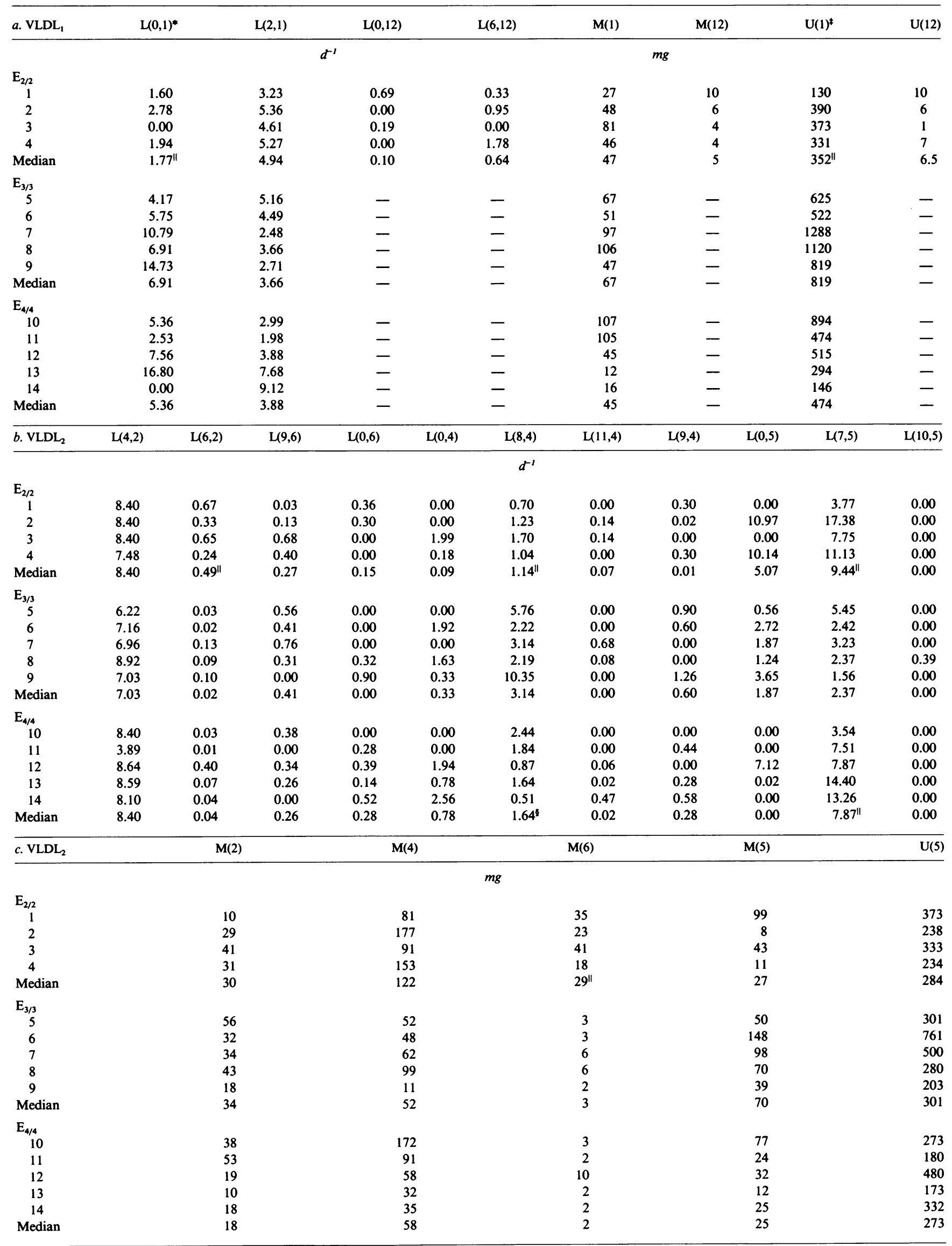


Table V. (Continued)



* Rate constants, $\mathrm{L}, \mathbf{k}$ (destination, source) and masses, $\mathrm{M}\left(\quad\right.$ ). ${ }^{\ddagger} \mathrm{U}(\quad$ ) represents de novo synthesis of apo B into a compartment. $\quad$ Significantly different from $\mathrm{E}_{3}$ group, $P<0.05$, " $P<0.02,{ }^{\top} P<0.01$. Difference between groups was assessed by the Mann-Whitney test.

Table VI. Comparison of Apo B Turnover in Normolipemic $E_{2}$ Homozygotes and Type III Hyperlipidemic Subjects before and during Bezafibrate Therapy

\begin{tabular}{|c|c|c|c|c|c|c|c|c|c|c|c|c|}
\hline \multirow[b]{2}{*}{ Subjects } & \multicolumn{3}{|c|}{$\mathrm{VLDL}_{1}$} & \multicolumn{3}{|c|}{$\mathrm{VLDL}_{2}$} & \multicolumn{3}{|c|}{ IDL } & \multicolumn{3}{|c|}{ LDL } \\
\hline & $\begin{array}{c}\text { Total } \\
\text { production }\end{array}$ & $\begin{array}{l}\text { Plasma } \\
\text { concn. }\end{array}$ & FCR & $\begin{array}{c}\text { Total } \\
\text { production }\end{array}$ & $\begin{array}{l}\text { Plasma } \\
\text { concn. }\end{array}$ & FCR & $\begin{array}{c}\text { Total } \\
\text { production }\end{array}$ & $\begin{array}{l}\text { Plasma } \\
\text { concn. }\end{array}$ & FCR & $\begin{array}{c}\text { Total } \\
\text { production }\end{array}$ & $\begin{array}{l}\text { Plasma } \\
\text { concn. }\end{array}$ & FCR \\
\hline & $m g / d$ & $m g / d l$ & $p o o l / d$ & $m g / d$ & $m g / d l$ & pools/d & $m g / d$ & $m g / d l$ & pools/d & $m g / d$ & $m g / d l$ & pools/d \\
\hline Type III* & & & & & & & & & & & & \\
\hline$(n=6)$ & 885 & 15.9 & 2.0 & 1125 & 30.8 & 1.2 & 630 & 13.7 & 1.3 & 439 & 21 & 0.21 \\
\hline Type III on & & & & & & & & & & & & \\
\hline bezafibrate & 385 & 2.9 & 4.5 & 783 & 14.6 & 1.7 & 568 & 14.0 & 1.2 & 138 & 17 & 0.33 \\
\hline$E_{2 / 2}$ normolipemic & 356 & 2.6 & 6.2 & 534 & 8.6 & 2.3 & 413 & 13.1 & 1.1 & 135 & 21 & 0.26 \\
\hline
\end{tabular}

* Data on type III hyperlipidemic subjects were taken from reference 35. 
subjects before and during bezafibrate treatment are presented in Table VI. There is a remarkable similarity between treated type III and normolipemic $\mathrm{E}_{2}$ subjects in both the apo B content of lipoprotein fractions and metabolic behavior indicating that bezafibrate removes the hyperlipidemia component from the type III pattern but does not correct the abnormality owing to $E_{2}$ genetic variant. Interestingly, before drug therapy the type III patients converted $76 \%$ of IDL to LDL (similar to the $E_{3}$ subjects in Table IV), whereas on treatment this fell to $26 \%$, i.e., close to the value seen in normolipemic $\mathrm{E}_{2}$ subjects. Thus bezafibrate had two effects; it reduced VLDL synthesis correcting the hyperlipidaemia (but not the dysbetalipoproteinemia) and altered the nature of the IDL to LDL metabolic link from that seen in $E_{3}$ to that seen in $E_{2}$ subjects.

There was no increase in the fractional clearance rate of LDL apo $\mathrm{B}$ in $\mathrm{E}_{2}$ homozygotes in the present study (Table IV d). This contrasts with an earlier preliminary report by Gregg et al. (12) in which a small increase in LDL FCR was observed in two normolipemic $\mathrm{E}_{2}$ homozygotes. However, further work by the same authors in an apo E-deficient patient demonstrated a normal catabolic rate for autologous LDL apo B (36, 37). The low LDL apo B level observed in that condition was due to reduced synthesis at $20 \%$ of normal and in general LDL kinetics in apo $\mathrm{E}$ deficiency were similar to those reported here for $\mathrm{E}_{2}$ subjects (Table IV $d$ ).

Apo $B$ metabolism in $E_{4}$ homozygotes. Apo B synthesis in VLDL $_{1}$ was lower in $\mathrm{E}_{4}$ than $\mathrm{E}_{3}$ subjects (Table IV $a$ ) but the difference was not significant. The circulating mass of apo $B$ and clearance rate of the fraction were similar in the two groups. Likewise, $\mathrm{VLDL}_{2}$ apo $\mathrm{B}$ synthesis, pool size, and overall catabolic rate were similar in $\mathrm{E}_{3}$ and $\mathrm{E}_{4}$ subjects as was the turnover of IDL (Table IV). However, calculation of the amount of apo B undergoing direct catabolism from VLDL $_{2}$ and IDL compared to that channeled down the delipidation cascade revealed that $\mathrm{E}_{4}$ homozygotes exhibited a relative decrease in direct removal and, per milligram of apo B entering VLDL $_{2}$, directed more towards LDL production (Table IV). Thus, despite the fact the $E_{4}$ subjects synthesized apo $B$ in VLDL (VLDL ${ }_{1}$ plus VLDL VI $_{2}$ ) at only two-thirds of the rate seen in $\mathrm{E}_{3}$ homozygotes (Table IV $a$ and $b$ ) they had apo B levels that were at least as high as those seen in the latter group (Table II). LDL levels in $\mathrm{E}_{4}$ subjects were further increased by the low FCR seen for apo B in this flotation interval (Tables IV $d$ and V $e$ ). This was due to a decrease in the rate of apo B degradation from the larger of the two LDL compartments (compartment 10 , Table $\mathrm{V} e$ ) with the result that both LDL pools were cleared at the same rate. This is consistent with a reduced receptor-mediated LDL clearance in $\mathrm{E}_{4}$ subjects. In fact, the concentration and distribution of apo $\mathrm{B}$-containing lipoproteins in $\mathrm{E}_{4}$ homozygotes appears to be the result of suppressed receptor-mediated catabolism of VLDL 2 , IDL, and LDL. It is likely that the low synthetic rate for apo $B$ observed in our $E_{4}$ group was a result of patient selection. $E_{4}$ homozygotes with an apo $B$ synthetic rate similar to that seen in the $E_{3}$ group $(800 \mathrm{mg} / \mathrm{d})$ would be predicted to have a plasma apo $B$ level of about $150 \mathrm{mg} / \mathrm{dl}$ and a plasma cholesterol in excess of $7.0 \mathrm{mmol} / \mathrm{liter}$.

Influence of apo E on apo B metabolism. It is clear from the above that variation in the apo $E$ gene has a profound impact on apo $B$ metabolism throughout the $S_{f}$ 0-400 lipoprotein spectrum. This information can be integrated with other studies on cholesterol metabolism (38) and chylomicron kinetics $(9,10)$ to generate an overall picture of the influence of the polymorphism which refines and in places corrects the model previously suggested by Davignon et al. (3). Cholesterol absorption from the gut is reportedly higher in $E_{4}$ vs. $E_{3}$ vs. $E_{2}$ subjects. This together with differential clearance rate of chylomicron remnants $\left(E_{4}>E_{3}>E_{2} ;\right.$ references 9 and 10$)$ will affect the delivery of intestinal (including dietary) cholesterol to the liver. The result is a predicted decrease in the hepatic sterol pool in $E_{2}$ vs. $E_{3}$ and $E_{4}$ subjects which gives rise to the observed graded difference $\left(E_{2}>E_{3}>E_{4}\right)$ in the rates of cholesterol and bile acid production $(38,39)$.

According to current concepts changes in the liver cholesterol pool will alter hepatic LDL receptor activity. The latter is predicted to be higher in $\mathrm{E}_{2}$ compared to $\mathrm{E}_{3}$ subjects and they in turn will be higher than $E_{4}$ subjects. Since we have found previously that $\mathrm{LDL}$ receptors play a role in $\mathrm{VLDL}_{2}$, IDL, and LDL metabolism $(13,27)$, this mechanism explains why $\mathrm{E}_{2}$ homoz' gotes exhibit more and $\mathrm{E}_{4}$ homozygotes less direct catabolism of $\mathrm{VLDL}_{2}$ and IDL than $\mathrm{E}_{3}$ subjects. In this scenario LDL removal should be increased in $\mathrm{E}_{2}$ homozygotes but this was not observed in our group (Table IV $d$ ) or in an apo E-deficient patient (37) possibly because the small amount of LDL that is present is abnormal, having a conformation of apo B that fails to recognize receptors efficiently. Evidence to support this hypothesis comes from studies of the kinetic behavior of LDL from apo $\mathrm{E}$-deficient or $\mathrm{E}_{2}$ homozygous subjects in normals; it is cleared more slowly than autologous $\operatorname{LDL}(12,37)$. In contrast, normal LDL given to an apo E-deficient patient is cleared rapidly as would be the case if LDL receptors were up-regulated (37). The redirection of the metabolic fate of IDL from conversion to LDL to direct catabolism in $E_{2}$ homozygotes may be further influenced by a requirement for functional apo $\mathrm{E}$ for lipolysis to proceed efficiently. In vitro studies suggest that VLDL from $\mathrm{E}_{2}$ subjects is not a good substrate for lipase and lipolysis of this lipoprotein does not lead to the formation of LDL (40). Addition of apo $E_{3}$ enhances the reaction and LDL is formed. Retarded delipidation would provide a mechanism for the formation of $\mathrm{VLDL}_{2}$ remnants and the very low conversion of IDL to LDL in our $E_{2}$ subjects. This integrated model, which is now modified and considerably strengthened by the availability of detailed apo B kinetic data, can be used to help explain why individuals with varying apo $E$ phenotypes respond differently to diet and drug therapies $(41,42)$.

\section{Acknowledgments}

The authors thank Patricia Price for her excellent secretarial help. This work was supported by grants from the British Heart Foundation $(87 / 6$ and 89/109). Dr. Demant was the recipient of a scholarship from Stiftung Volkswagen, Hanover, Federal Republic of Germany.

\section{References}

1. Utermann, G. 1975. Isolation and partial characterization of an argininerich apolipoprotein from human plasma very low density lipoproteins: apolipoprotein E. Hoppe-Seyler's Z. Physiol. Chem. 356:1113-1121.

2. Zannis, V. I., and J. L. Breslow. 1981. Human very low density lipoprotein apolipoprotein $\mathrm{E}$ isoprotein polymorphism is explained by genetic variation and post-translational modification. Biochemistry. 20:1033-1041.

3. Davignon, J., R. E. Gregg, and C. F. Sing. 1988. Apolipoprotein E polymorphism and atherosclerosis. Arteriosclerosis. 8:1-21.

4. Mahley, R. W., T. L. Innerarity, S. C. Rall, and K. H. Weisgraber. 1984 Plasma lipoproteins: apolipoprotein structure and function. J. Lipid Res. 25:1277-1294. 
5. Menzel, H. J., and G. Utermann. 1986. Apolipoprotein E phenotyping from serum by Western blotting. Electrophoresis. 7:492-495.

6. Havekes, L. M., P. de Knijff, U. Beisiegel, J. Havinga, M. Smit, and E. Klasen. 1987. A rapid micromethod for apolipoprotein $E$ phenotyping directly in serum. J. Lipid Res. 28:455-463.

7. Weisgraber, K. H., T. L. Innerarity, and R. W. Mahley. 1982. Abnormal lipoprotein receptor-binding activity of the human $\mathrm{E}$ apolipoprotein due to cysteine-arginine interchange at a single site. J. Biol. Chem. 257:2518-2521.

8. Utermann, G., M. Hees, and A. Steinmetz. 1977. Polymorphism of apolipoprotein $\mathrm{E}$ and occurrence of dysbetalipoproteinaemia in man. Nature (Lond.). 269:604-607.

9. Weintraub, M. S., S. Eisenberg, and J. L. Breslow. 1987. Dietary fat clearance in normal subjects is regulated by genetic variation in apolipoprotein $\mathrm{E} . J$. Clin. Invest. 80:1571-1577.

10. Brenninkmeijer, B. J., P. M. J. Stuyt, P. N. M. Demacker, A. F. H. Stalenhoef, and A. van't Larr. 1987. Catabolism of chylomicron remnants in normolipidaemic subjects in relation to the apoprotein $\mathrm{E}$ phenotype. J. Lipid Res. 28:361-370

11. Turner, P. R., C. Cortese, R. Wootton, C. Marenah, N. E. Miller, and B. Lewis. 1985. Plasma apolipoprotein B metabolism in familial type III dysbetalipoproteinaemia. Eur. J. Clin. Invest. 15:100-112.

12. Gregg, R. E., L. A. Zech, C. Gabelli, D. Stark, D. Wilson, and H. B. Brewer, Jr. 1984. LDL metabolism in normolipidemic apoE ${ }_{2}$ homozygotes. Circulation. 70:II-312. (Abstr.)

13. James, R. W., B. Martin, D. Pometta, J. C. Fruchart, P. Duriez, P. Puchois, J. P. Farreaux, A. Tacquet, T. Demant, R. J. Clegg, et al. 1989. Apolipoprotein B metabolism in homozygous familial hypercholesterolemia. J. Lipid Res. 30:159-169.

14. Zannis, V. I., J. L. Breslow, G. Utermann, R. W. Mahley, K. H. Weisgraber, R. J. Havel, J. L. Goldstein, M. S. Brown, G. Schonfeld, W. R. Hazzard, et al. 1982. Proposed nomenclature of apoE isoproteins, apoE genotypes, and phenotypes. J. Lipid Res. 23:911-914.

15. Paul, A. A., and D. A. T. Southgate, editors. 1978. McCance and Widdowson's: The Composition of Food. Her Majesty's Stationery Office, London.

16. Lipid Research Clinics Program Manual of Laboratory Operations. 1975. DHEW Publications, No. (NIH) 75-268. Government Printing Office, Washington, DC.

17. Towbin, H., T. Staehelin, and J. Gordon. 1979. Electrophoretic transfer of proteins from polyacrylamide gels to nitrocellulose sheets: procedure and some applications. Proc. Natl. Acad. Sci. USA. 76:4350-4354.

18. Packard, C. J., A. Munro, A. R. Lorimer, A. M. Gotto, and J. Shepherd. 1984. Metabolism of apolipoprotein B in large triglyceride-rich very low density lipoproteins of normal and hypertriglyceridemic subjects. J. Clin. Invest. 74:2178-2192.

19. Bilheimer, D. W., S. Eisenberg, and R. I. Levy. 1982. The metabolism of very low density lipoprotein proteins. I. Preliminary in vitro and in vivo observations. Biochim. Biophys. Acta. 260:212-221.

20. Lindgren, F. T., C. L. Jensen, and F. T. Hatch. 1972. The isolation and quantitative analysis of serum lipoproteins. In Blood Lipids and Lipoproteins: Quantitation, Composition and Metabolism. G. J. Nelson, editor. Wiley-Interscience, New York. 221-245.

21. Kane, J. P., T. Sata, R. L. Hamilton, and R. J. Havel. 1975. Apoprotein composition of very low density lipoproteins of human serum. J. Clin. Invest. 56:1622-1634.

22. Lowry, O. H., N. J. Rosenbrough, A. L. Farr, and R. J. Randall. 1951. Protein measurement with the folin phenol reagent. J. Biol. Chem. 193:265-275.

23. Shepherd, J., C. J. Packard, S. M. Grundy, D. Yeshurun, A. M. Gotto, and O. D. Taunton. 1980. Effects of saturated and polyunsaturated fat diets on the chemical composition and metabolism of low density lipoproteins in man. $J$. Lipid Res. 21:91-99.

24. Berman, M., and M. F. Weiss. 1974. SAAM Manual. U. S. Public Health Service Publication No. 1703. U. S. Government Printing Office, Washington, DC.

25. Berman, M., M. Hall III, R. I. Levy, S. Eisenberg, D. W. Bilheimer, R. D.
Phair, and R. M. Goebel. 1978. Metabolism of apoB and apoC lipoproteins in man: kinetic studies in normal and hyperlipoproteinemic subjects. J. Lipid Res. 19:38-56.

26. Demant, T., L. A. Carlson, L. Holmquist, F. Karpe, P. Nilsson-Ehle, C. J. Packard, and J. Shepherd. 1988. Lipoprotein metabolism in hepatic lipase deficiency: studies on the turnover of apolipoprotein B and on the effect of hepatic lipase on high density lipoprotein. J. Lipid Res. 29:1603-1611.

27. Packard, C. J., D. E. Boag, R. Clegg, D. Bedford, and J. Shepherd. 1985. Effects of 1,2-cyclohexanedione modification on the metabolism of very low density lipoprotein apolipoprotein B: potential role of receptors in intermediate density lipoprotein catabolism. J. Lipid Res. 26:1058-1066.

28. Stalenhoef, A. F., M. J. Malloy, J. P. Kane, and R. J. Havel. 1984. Metabolism of apolipoproteins B48 and B100 of triglyceride rich lipoproteins in norma and lipoprotein lipase deficient humans. Proc. Natl. Acad. Sci. USA. 81:18371843.

29. Nikkila, E. A. 1983. Familial lipoprotein lipase deficiency and related disorders of chylomicron metabolism, In Disorders of Lipoprotein and Lipid Metabolism. J. B. Stanbury, J. B. Wyngaarden, D. S. Fredrickson, J. L. Goldstein and M. S. Brown, editors. McGraw-Hill Book Co., Inc., New York. 622-642.

30. Goldberg, I. J., N. A. Le, H. N. Ginsberg, R. M. Krauss, and F. T. Lindgren. 1988. Lipoprotein metabolism during acute inhibition of lipoprotein lipase in the cynomolgus monkey. J. Clin. Invest. 81:561-568.

31. Herz, J., U. Hamann, S. Rogne, O. Myklebost, H. Gausepohl, and K. K. Stanley. 1988. Surface location and high affinity for calcium of a $500 \mathrm{kD}$ liver membrane protein closely related to the LDL-receptor suggest a physiological role as lipoprotein receptor. EMBO (Eur. Mol. Biol. Organ.) J. 7:4119-4127.

32. Kowal, R. J. Herz, K. H. Weisgraber, R. W. Mahley, M. S. Brown, and J. L. Goldstein. 1990. Opposing effects of apolipoproteins $E$ and $C$ on lipoprotein binding to low density lipoprotein receptor-related protein. J. Biol. Chem. 265:10771-10779.

33. Bradley, W S.-L. Hwang J. B. Karlin, A. H. Y. Lin, S. C. Prasad A. M Gotto, and S. H. Gianturco. 1984. Low density lipoprotein receptor-binding determinants switch from apolipoprotein $\mathrm{E}$ to apolipoprotein $\mathrm{B}$ during conversion of hypertriglyceridaemic very low density lipoprotein to low density lipoproteins. J. Biol. Chem. 259:14728-14735.

34. Krul, E. S., M. J. Tikkanen, T. G. Cole, J. M. Davie, and G. Schonfeld. 1985. Roles of apolipoprotein $B$ and $E$ in the cellular binding of very low density lipoproteins. J. Clin. Invest. 75:361-369.

35. Packard, C. J., R. J. Clegg, M. H. Dominiczak, A. R. Lorimer, and J. Shepherd. 1986. Effects of bezafibrate on apolipoprotein B metabolism in type III hyperlipoproteinemic subjects. J. Lipid Res. 27:930-938.

36. Schaefer, E. J., R. E. Gregg, G. Ghiselli, T. M. Forte, J. M. Ordovas, L. A. Zech, and M. B. Brewer. 1986. Familial apolipoprotein E deficiency. J. Clin. Invest. 78:1206-1219.

37. Gabelli, C., R. E. Gregg, L. A. Zech, E. Manzato, and H. B. Brewer, Jr. 1986. Abnormal low density lipoprotein metabolism in apolipoprotein $\mathrm{E}$ deficiency. J. Lipid Res. 27:326-333.

38. Kesaniemi, Y. A., C. Ehnholm, and T. A. Miettinen. 1987. Intestinal cholesterol absorption efficiency in man is related to apoprotein $\mathrm{E}$ phenotype. $J$. Clin. Invest. 80:578-581.

39. Angelin, B., L. Holmquist, B. Leijd, and K. Einarsson. 1990. Bile acid metabolism in familial dysbetalipoproteinaemia: studies in subjects with the apolipoprotein $\mathrm{E}_{2 / 2}$ phenotype. Eur. J. Clin. Invest. 20:143-149.

40. Ehnholm, C., R. W. Mahley, D. A. Chappell, K. H. Weisgraber, and J. L. Witztum. 1984. Role of apolipoprotein $\mathrm{E}$ in the lipolytic conversion of $\beta$-very low density lipoproteins to low density lipoproteins in type III hyperlipoproteinemia. Proc. Natl. Acad. Sci. USA. 81:5566-5570.

41. Eto, M., T. Sato, K. Watanabe, Y. Iwashima, and I. Makino. 1990. Effects of probucol on plasma lipids and lipoproteins in familial hypercholesterolaemic patients with and without apolipoprotein $\mathrm{E}_{4}$. Atherosclerosis. 84:49-53.

42. Tikkanen, M. J., J. K. Huttunen, C. Ehnholm, and P. Pietinen. 1990. Apolipoprotein $\mathrm{E}_{4}$ homozygosity predisposes to serum cholesterol elevation during high fat diet. Arteriosclerosis. 10:285-288. 